\title{
Correction to: Preparation and properties of fly ash-based geopolymer concrete with alkaline waste water obtained from foundry sand regeneration process
}

\author{
S. M. Fuad Kabir Moni ${ }^{1} \cdot$ O. Ikeora ${ }^{1}$. C. Pritzel ${ }^{1} \cdot$ B. Görtz ${ }^{1} \cdot$ R. Trettin ${ }^{1}$
}

Published online: 15 June 2021

(c) The Author(s) 2021

\section{Correction to: \\ Journal of Material Cycles and Waste Management (2020) 22:1434-1443 https://doi.org/10.1007/s10163-020-01032-3}

The article "Preparation and properties of fly ash-based geopolymer concrete with alkaline waste water obtained from foundry sand regeneration process", written by S. M. Fuad Kabir Moni, O. Ikeora, C. Pritzel, B. Görtz, R. Trettin, was originally published Online First without Open Access. After publication in volume 22, issue 5, page 1434-1443 the author decided to opt for Open Choice and to make the article an Open Access publication. Therefore, the copyright of the article has been changed to (C) The Author(s) 2021 and the article is forthwith distributed under the terms of the Creative Commons Attribution 4.0 International License, which permits use, sharing, adaptation, distribution and reproduction in any medium or format, as long as you give appropriate credit to the original author(s) and the source, provide a link to the Creative Commons licence, and indicate if changes were made. The images or other third party material in this article are included in the article's Creative Commons licence, unless indicated otherwise in a credit line to the material. If material is not included in the article's
Creative Commons licence and your intended use is not permitted by statutory regulation or exceeds the permitted use, you will need to obtain permission directly from the copyright holder. To view a copy of this licence, visit http:// creativecommons.org/licenses/by/4.0/.

The original article has been updated.

Open Access This article is licensed under a Creative Commons Attribution 4.0 International License, which permits use, sharing, adaptation, distribution and reproduction in any medium or format, as long as you give appropriate credit to the original author(s) and the source, provide a link to the Creative Commons licence, and indicate if changes were made. The images or other third party material in this article are included in the article's Creative Commons licence, unless indicated otherwise in a credit line to the material. If material is not included in the article's Creative Commons licence and your intended use is not permitted by statutory regulation or exceeds the permitted use, you will need to obtain permission directly from the copyright holder. To view a copy of this licence, visit http://creativecommons.org/licenses/by/4.0/.

Publisher's Note Springer Nature remains neutral with regard to jurisdictional claims in published maps and institutional affiliations.

The original article can be found online at https://doi.org/10.1007/ s10163-020-01032-3.

\footnotetext{
S. M. Fuad Kabir Moni

kabir@chemie.uni-siegen.de

1 Institute for Building and Materials Chemistry, University of Siegen, Paul Bonatz Str. 9-11, 57068 Siegen, Germany
} 